\title{
The Contribution of Financial Literacy towards Poverty Alleviation in Cameroon
}

\author{
Susannash Limunga Esowe \\ ICT University USA, Cameroon Campus, Cameroon \\ E-mail: mboh.susannash@ictuniversity.org \\ Michael Nkam Cho \\ ICT University USA, Cameroon Campus, Cameroon \\ E-mail: nkam.michael@ictuniversity.org
}

Alain Vilard Ndi Iso

ICT University USA, Cameroon Campus, Cameroon

E-mail: alainvilard.isoh@ictuniversity.org

Received: Dec. 14, 2017 Accepted: December 22, 2017 Published: December 31, 2017

doi:10.5296/bms.v8i2.12301ＵRL: https://doi.org/10.5296/bms.v8i2.12301

\begin{abstract}
Poverty in most cases is measured taking into consideration the financial wellbeing of the individuals concern. Financial wellbeing on the other hand does not only depend on accumulation of financial resources but as well on the acquisition of knowledge on financial sustainability.

This study seeks to analyze the contribution of financial literacy to poverty alleviation in Cameroon, taking into consideration the financial literacy level of workers and the households in general.

The study that was conducted in Yaoundé- Cameroon made use of both qualitative and quantitative research methods with the aid of questionnaires and interviews. Through a
\end{abstract}


purposive sampling technique, a sample of some 100 respondents made up of workers was administered questionnaires, and the views of some 20 retired persons were sampled on their knowledge on the available financial instruments, and how these instruments were used to enhance their financial wellbeing and sustainability at retirement age.

The data collected was analyzed with the use of SPSS, and the results were presented in the form of descriptive statistics. The findings showed that a significant proportion of workers in Cameroon are not familiar with the available financial instrument, and were greatly engaged in reckless borrowing without knowing the consequences of such actions.; Result from the interview revealed that a great majority of workers only think of retirement provisions when they approach retirement age. Based on this study, the need for sustainability in financial literacy to Cameroon workers with the intention to alleviate poverty remains a top policy recommendation.

Keywords: Financial wellbeing, Financial literacy, Financial education, Poverty alleviation, Financial sustainability, Cameroon 


\section{Introduction}

According to the United Nations Sustainable Development Goal of 2016, Poverty alleviation is a focal point of every economic and social policy designed to be achieved through a configuration of integrated action of both the government and non-governmental stakeholders. The achievement of financial sustainability is dependent on the level of financial literacy established by concerned stakeholders interested in narrowing the poverty gap in Cameroon.

Globally, consumers of financial services and especially the vulnerable groups exhibit insufficient knowledge on financial instruments and principles. Most individuals fail to plan for the future and are unable to make financial decisions that meet up with their needs. The consequences thereof are not limited to individuals and household well-being, but the long term viability and stability of the global financial and economic systems (Russia G20 et al, 2013). According to the Policy Brief Report of Organization for Economic Co-operation and Development (OECD), July 2016, stressing on the importance of financial education, revealed that with adequate knowledge on financial related matters both investors and families will be able to provide answers to questions such as: how to acquire a home, fund the children's education and ensure an income after retirement.

OECD (2016) observes that the growing sophistication of financial markets exposes consumers to a variety of complex financial instruments for borrowing and saving, with a large range of options. Given that the risks of these services are shifted by employers and government to workers, this situation must be handled with a lot of care since wrong financial decisions will have impacts on individual's life especially after retirement.

The present situation in Cameroon indispensably requires financial education given that more and more financial instruments are made available to the population which is not yet financially literate. This is supported by the works of Xu and Zia (2012), titled "review of financial theory across the globe" in which survey results in Sub-Saharan Africa indicated that a large proportion of population in these countries lack awareness of basic financial products and concepts such as savings accounts, interest on savings, insurance and loans. Technological innovations within the financial services in Cameroon such as debit card facilities, mobile money transactions and others have rendered money so liquid that it can easily flow from one point to another, and hence the greater need of education for financial management. This is however a general problem as Lusardi and Mitchelli (2011); Klapper et al. (2012) opine that improving financial literacy and financial capability benefits people both in developed and developing countries.

Due to the presence of insufficient institutions that provide services in financial education to the Cameroon population, majority of the customers are frequently exposed to many financial risks, such as bank clients signing certain contracts with terms and conditions without properly understanding the implications of such contracts.

However, financial literacy does not only have effects on individuals but also on the financial system and the domestic economy. This is evidence based on the review of financial literacy 
studies implemented in different parts of the world. Capuano and Ramsey (2011) categorized the benefactors of financial education into three main categories; namely: individuals, financial system and the economy. Specific benefits to an individual as indicated by Capuano and Ramsey (2011) included: increase savings and retirement planning; more realistic assessment of financial knowledge by consumers; financial efficiency in the domain of lifetime utility and financial wellbeing together with debt management; investing and choosing the right financial products with confidence; and consumer rights and regulatory intervention. The benefits to financial system and economy include: greater competition, innovation and quality products; and understanding government financial policies.

The effects of financial illiteracy become more severe on the individuals especially when they are retired due to the lack of the knowledge on savings, investments and social security which could have been acquired through retirement seminars. Lusardi (2003) observed that the provision of financial education via retirement seminars fosters savings and investment in stock. On the other hand, some employees only understand the notion of saving in their life-cycles very late, when already approaching retirement. Lusardi (2002) opines that many households have limited resources until late in their life-cycles, or they start saving so late that it is impossible to accumulate much. He further notes that older workers only plan for retirement five to ten years from retirement. Gustman and Steinmeier (1999) on their part report that many workers are poorly informed about their social security and pension benefits and they often err about the type of pension plan they have and the benefits associated to it. Bernheim (1998) and Macfarland et al. adhered that workers are ill-equipped to make saving plans. Many people are therefore subjected to abject poverty upon retirement because of failure to plan and in time coupled with the fact that their employers do not assist them.

Cameroon with her vision of becoming an emergent economy by 2035 has an obligation to equip her citizens with all what it takes for a country to emerge. This can partly be achieved if the households and other stakeholders are financially knowledgeable thereby ensuring its financial wellbeing. This study seeks to elucidate the role of financial literacy in a bid to alleviate poverty in Cameroon through the proper management of the available financial instruments and subsequent financial innovations.

\section{Review of Related Works}

Literature on financial literacy is still scanty given that much interest on this concept has been developed with the evolution of modern and sophisticated financial instruments with different definitions. According to Organization for Economic Co-operation and Development financial literacy is the process by which financial consumers/investors improve their understanding of financial products, concepts and risks, and through information develop the skills and confidence to become more aware of financial risks and opportunities, to make informed choices, to know where to go to for help, and to take other effective actions to improve their financial well-being.

Starcek and Trunk (2013) on their part opined that the financial needs of individuals have 
become more and more complicated and pretentious that they can only use the appropriate knowledge in the field of finances, pension schemes and taxes to improve their understanding in financial products, service and concepts, and develop skills they need for improving their financial literacy. According to the Master Card Foundation Report (2011), "Financial education refers to the process of introducing people to the knowledge, skills and attitudes required for responsible earning, spending, saving borrowing and investing”. Most individuals adhere to financial instruments without a proper understanding of the functioning of these products and services as well as the applicable rules; such that they often than not misuse their money. Cohen et al (2011) intimated that by increasing people's understanding of the various financial instruments and "rules of the game", financial education transmits skills for the proper adoption and use of financial products and services. They opine that financial education promotes behavioral pattern that contributes to the effective use of economic resources.

According to the Master Card Foundation Report (2011), "when people have low levels of financial literacy, they often make unproductive financial decisions: they spend their money in sub optimal ways, borrow too much, save too little and miss opportunities for investing”. This report further highlights that by communicating financial education on proper finance management; individuals can better use their finances in a more effective manner and cohere to the financial instruments that meet their needs. With technological innovation trends for financial services, financial education becomes indispensable for decision making. Customers of financial services are offered a broad spectrum of complex financial instrument by several providers. Most often, consumers adhere to financial services contracts that rather subject them to poverty. Financial education is widely gaining ground as a major determinant for the socio economic well-being and livelihoods of the people. Many individuals and households are not familiar with the elementary economic concepts necessary to establish savings and investment decisions. This explains the absence of retirement planning as well as households getting so close to retirement with insufficient or no wealth to sustain them thereof (Lusardi et al 2007).

Van Rooij et al (2011) opine that a greater proportion of individuals exhibit basic financial knowledge and a mastery of some of the basic concepts. However, very few individuals have knowledge on stock market operations. Also, those with little knowledge on financial education hardly invest in stocks. Stressing on the strong relationship between financial education, financial services access and poverty reduction; Khandker (1998) posits that microcredit programs are an effective policy instrument for poverty reduction amongst the poor with the capacity to become self-employed. Khandker (2005) also intimated that access to microfinance play an important role for poverty reduction especially for the female population and the entire community as a whole. Burgess et al (2003) opines that rural branch expansion program significantly reduces rural poverty. However, all these programs to access finance can only be beneficial if the said community or population have knowledge on their usage. This will imply using finances that is appropriate to the needs of the individuals, households, community or firms. Capuano and Ramsey (2011) postulate that financial literacy is beneficiary to individuals, financial system and the economy. Some of these benefits are: 
- $\quad$ Financial literacy can increase employee responsibility for managing their proper investments towards a retirement and pension plans (Braunstein et al, 2002).

- $\quad$ Financial literacy contributes towards the initiation of branchless banking to ease consumers' access to financial instruments.

- $\quad$ Financial literacy enables individuals and households to balance up their budgets as well as create an increased awareness on a healthy financial state.

- $\quad$ With financial literacy, individuals and households can weigh the risk associated with sophisticated financial instruments.

- $\quad$ Financial literacy can enable consumers to transact with the financial sector by contributing effectively to the actual economic growth as well as alleviate poverty (OECD Policy Brief, 2006). This Policy Brief further highlights that "individuals will not be able to choose the right savings or investments for themselves, and may be at risk of fraud if they are not financially literate. But if individuals do become financially educated, they will be more likely to save and to challenge financial service providers to develop products that truly responds to their needs and that should have positive effects on both investments levels and economic growth".

Financial literacy facilitates individuals and household's wealth accumulation. Financial education promotes investment in the stock market whereby the investors will benefit the profit that might accrue thereof. Also, financial education is strongly related to retirement and savings plan which has the potential of boosting wealth (Van Rooij et al, 2012).

\section{Research Methodology}

This is an exploratory study that made use of both quantitative and qualitative research methods.

A pragmatic philosophy was used to understand the nature of knowledge based on two philosophical orientations principally viewed from an angle of subjectivity within the framework of interpretivist epistemology, and from the analysis of questionnaires using the postulation of positivism. This philosophical orientation further implies that the study supports the continuum methodology and the proposed research designed to arrive at a logical conclusion were reasoned from two central positions; i.e both deductive and inductive reasoning.

Interviews were conducted, and questionnaires were administered to some selected respondents such as retirees and workers still in active service with the intention to assess their knowledge on the available financial instruments and their awareness of their consequences. One hundred questionnaires were sent out and ninety-one were returned and analyzed. Twenty retirees were interviewed on aspects relating to their preparedness for retirement using their financial knowledge, the available financial instruments, and their financial wellbeing after retirement. 


\section{Data Analysis and Results.}

The data collected for this study were analyzed using EXCEL and SPSS 17 software. The results were presented using descriptive statistics in the form of pie charts, bar charts, frequency tables, and cross-tabulations.

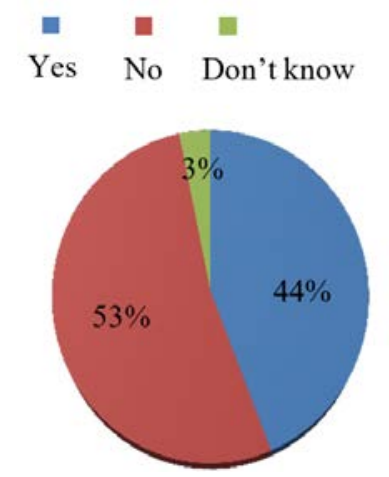

Figure 1. Pie chart presenting the opinions of workers on whether their household have monthly budget

Source: Researcher’s field work data analysis (2017).

The results show that $53 \%$ of the sampled population do not have monthly budget for their household and $44 \%$ do. Three percent of the respondents do not even understand what monthly budget for a household mean.

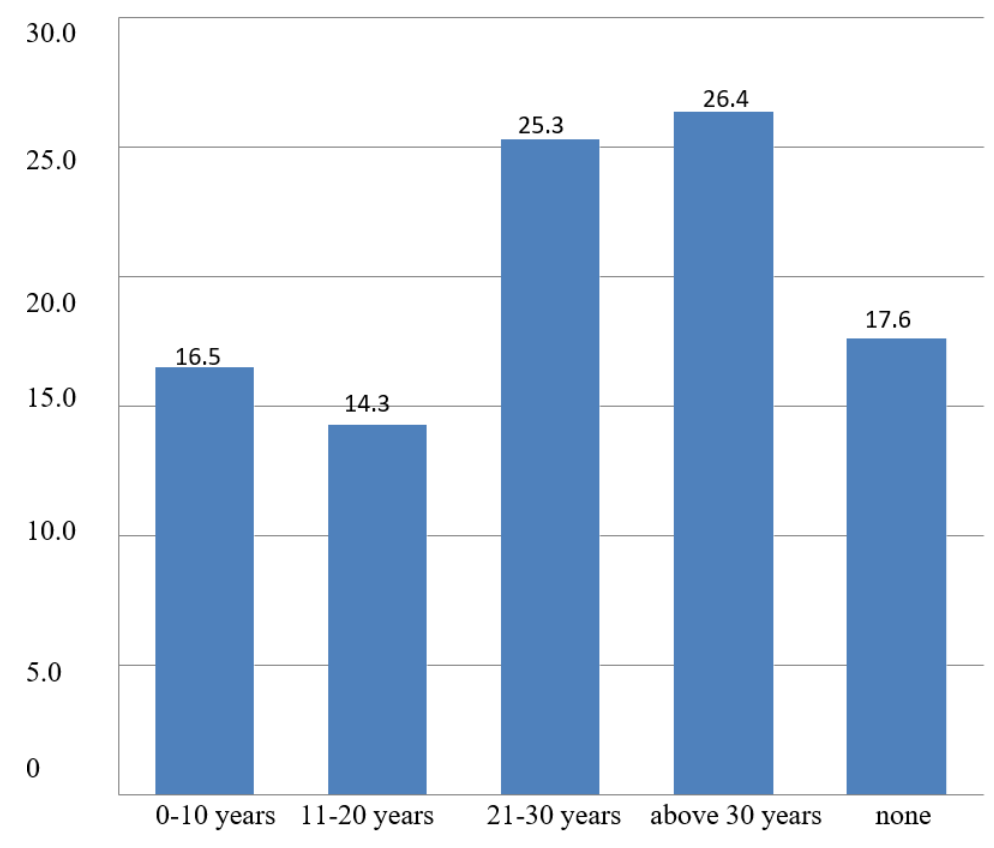

Figure 2. Bar chart presenting the opinions of respondents on when they start preparing for retirement while in active service

Source: Researcher’s field work data analysis (2017). 
The results show that most of the workers only start to prepare for their retirement when they are already approaching retirement. From the statistics, $51.7 \%$ of the sampled population indicated that they start to prepare for retirement after working at least for 21 years. Only about $16.5 \%$ of the respondents start preparing for retirement as soon as they start working. It is worth noting that $17.6 \%$ of the sampled population does not even think of retirement when working.

Table 1. Presenting the views of Respondents if they have been exposed to retirement seminars

\begin{tabular}{|l|l|l|}
\hline & Frequency & Percent \\
\hline Yes & 8 & 8.8 \\
\hline No & 79 & 86.8 \\
\hline Neutral & 4 & 4.4 \\
\hline TOTAL & $\mathbf{9 1}$ & $\mathbf{1 0 0 . 0}$ \\
\hline
\end{tabular}

Source: Researcher's field work data analysis (2017).

Asked whether they have ever been exposed to retirement seminars when still in active service, $86.8 \%$ of the respondents denied that they have never had such an opportunity, while just $8.8 \%$ of the workers have been exposed to retirement seminars. Some of the respondents seem not to even have an idea about retirement seminars, representing $4.4 \%$ of the respondents.

Table 2. Presenting the views of the respondents on what they do when they run out of money before the next income arrives

\begin{tabular}{|l|l|l|}
\hline & Frequency & Percent \\
\hline Spend our savings & 22 & 24.2 \\
\hline Take a bank overdraft & 35 & 38.5 \\
\hline We sell our securities/ shares & 3 & 3.3 \\
\hline Borrow from other sources & 31 & 34.1 \\
\hline Total & $\mathbf{9 1}$ & $\mathbf{1 0 0 . 0}$ \\
\hline
\end{tabular}

Source: Researcher's field work data analysis (2017).

Most of the respondents indicated that they would either borrow from other sources or take a bank overdraft when they run out of money before the next income arrives. This is confirmed by the response of $34.1 \%$ and $38.5 \%$ respectively. However, $24.2 \%$ would spend their savings while just about $3.3 \%$ would sell their securities to live on.

Table 3. Presenting the responses whether the workers clearly understand the terms and conditions of the available financial instruments before undertaking the various contracts

\begin{tabular}{|l|l|l|}
\hline & Frequency & Percent \\
\hline Yes & 32 & 35.2 \\
\hline No & 54 & 59.3 \\
\hline Neutral & 5 & 5.5 \\
\hline Total & $\mathbf{9 1}$ & $\mathbf{1 0 0 . 0}$ \\
\hline
\end{tabular}

Source: Researcher’s field work data analysis (2017). 


\section{Ml Macrothink}

It shows that just about $35.2 \%$ of the respondents clearly understand the implications of the various financial instruments before undertaking contracts while $59.3 \%$ would just agree without understanding the terms and conditions.

Table 4. Correlation between income level and savings/investments

\begin{tabular}{|l|l|l|l|l|l|}
\hline & Value & Asymp.Std. Error & Approx. T $^{\mathbf{D}}$ & $\begin{array}{l}\text { Approx. } \\
\text { Sig. }\end{array}$ \\
\hline $\begin{array}{l}\text { Interval } \\
\text { By Interval }\end{array}$ & Pearson's R & -.028 & .098 & -.267 & $.790^{\mathrm{C}}$ \\
\hline $\begin{array}{l}\text { Ordinal } \\
\text { By Ordinal }\end{array}$ & $\begin{array}{l}\text { Spearman } \\
\text { Correlation }\end{array}$ & -.047 & .102 & -.441 & $.660^{\mathrm{C}}$ \\
\hline No. of Valid Cases & $\mathbf{9 1}$ & & & \\
\hline
\end{tabular}

Source: Researcher’s field work data analysis (2017).

The correlation between income level and savings is negative with a Pearson's $\mathrm{R}$ value of -0.028 , showing that even when people earn much money the tendency to save is low.

Table 5. Presenting the respondent's level of education and their knowledge on financial instruments.

\begin{tabular}{|c|c|c|c|c|c|}
\hline & & \multicolumn{3}{|c|}{$\begin{array}{l}\text { Within which category do you belong with knowledge of } \\
\text { the available financial instruments in Cameroon such as } \\
\text { Treasury bonds, company shares/securities, overdraft, } \\
\text { debit cards, mobile money? }\end{array}$} & \multirow[b]{3}{*}{ Total } \\
\hline & & all & some of them & None & \\
\hline & & & & & \\
\hline \multirow{3}{*}{$\begin{array}{l}\text { Level of } \\
\text { Education }\end{array}$} & primary & 0 & 4 & 2 & 6 \\
\hline & secondary & 3 & 13 & 5 & 21 \\
\hline & tertiary & 5 & 52 & 7 & 64 \\
\hline \multicolumn{2}{|l|}{ Total } & 8 & 69 & 14 & 91 \\
\hline
\end{tabular}

Source: Researcher's field work data analysis (2017).

Of the 91 respondents, 64 were of tertiary education level while 21 were of secondary and just 6 of primary education level. Only 8 respondents were aware of all the available financial instruments while 14 of them were not even aware of any of the instruments available.

\section{Discussion}

The results analyzed above together with the answers obtained from the interviews clearly confirmed the effects of financial literacy on poverty. The fact that most of the households do 
not budget for the month will render savings difficult since expenditure is always inelastic. This is in tandem with Bernheim et al., (1998) who show that workers are ill-equipped to make saving plans. The results obtained also indicate that many workers only think of planning for retirement very late supporting the findings of Lusardi (2002) that older workers only plan for retirement five to ten years from retirement and it is impossible to accumulate much. These findings were also supported by answers from some retirees who affirmed that what they receive as pension and other investments cannot fund their children education because they started planning for retirement late. Almost $90 \%$ of the workers were never exposed to retirement seminars, reason why they did not plan well for their retirements.

This is contrary to the view of Lusardi (2003) who opines that the provision of financial education via retirement seminars fosters savings and investments in stock. The fact that most of the workers embark on overdraft and borrow when they run out of money and given that they do not understand the terms and conditions of their transactions well always render them poor since interests imputed on such overdraft are usually very high. This is in line with the report of a Finscope Survey (2003) in Uganda which pointed out that an overall low level of financial education in the country where majority of adults lack basic concepts of personal finance and unable to comprehend issues such as interest rates, discount rate, and money lending hindered access to finance. The results also show that the level of income of a household does not affect its savings and investments. This means that they do not save or invest not because their incomes are low but because of lack of the necessary financial knowledge on how to manipulate the available financial instrument.

In addition, these results concord to the findings of Capuano and Ramsey (2011) who state that some of the benefits of financial literacy are increase savings and retirement planning together with financial efficiency in the domain of lifetime utility and financial wellbeing. The results reveal that the higher the level of education of an individual, the higher the possibilities of their financial literacy. The results also show that many workers are not aware of all the available financial instruments and hence will always make wrong financial decisions with their applications. This is supported by the findings of $\mathrm{Xu}$ and Zia (2012) which revealed that a large proportion of Sub-Saharan African countries lack awareness of basic financial products and concepts such as saving accounts, interest on savings, insurance and loans.

Implications of Findings: Given that both individuals and the country benefit from financial education, it is the duty of the state of Cameroon to ensure that her citizens are financially literate. This can be done through training seminars. Employees should be educated on how to carry out their monthly budgeting so as to be able to save and invest. Apart from the social security schemes employees should plan for their retirement as soon as they start to work and earn a salary. This can be done through organizing retirement seminars. Clients should make sure they read contract terms and conditions and understand them well before engaging into such deals with financial institutions. The policy makers should come out with clear regulations protecting workers by stating the obligations of the employers to employees. 


\section{Conclusion}

Poverty alleviation is a concern of all countries in general and Cameroon in particular due to her poor economic performance. This study clearly shows that people do not get poor because they do not earn money but because they lack the necessary knowledge to manage what they earn. More poverty is noticed when workers are retired due to failure to plan for retirement while in active service. Many workers do not understand the concept of savings and investments and turn to spend all what they earn on consumer goods. Financial literacy therefore has a great contribution towards poverty alleviation in Cameroon.

Limitations: This study encountered many challenges ranging from the fact that most of the interviewees were reticent to give out information. The study was carried out only in Yaoundé, the capital of Cameroon and so generalization of findings may not be very realistic. We suggest that further study on the same aspect can be carried out in at least seven regions of Cameroon so that policies can be formulated properly based on the findings. Another research can also be conducted to find out the financial literacy level of non-salaried earners in Cameroon.

\section{References}

Annamaria, L. (2003). Saving and the effectiveness of financial education: Pension Research Working Paper.

Bernheim, B. D. (1998). Financial Illiteracy, Education and Retirement Saving” In living with defined Contribution Pensions. eds. Olivia Mitchell and Sylvester Schieber, Philadelphia, University of Pennsylvania Press: 38-68.

Braunstein, S., \& Welch, C. (2002). Financial Literacy: An Overview of Practice, Research and Policy. Fed. Res. Bull., 88, 445.

Burgess, R., \& Rohini, P. (2003). Do Rural Banks Matter? Evidence from the Indian Social Banking Experiment. Evidence from the Indian Social Banking Experiment (August 2003).

Capuano, A. R. (2011). What causes suboptimal Financial Literacy and Financial Behaviour? An explanation of Financial Literacy, Social influences and behavioural economics. Research Report, Financial Literacy and Financial Behaviour Financial Literacy Project.

Cohen, M., \& Nelson, C. (2011). Financial Literacy: A Step for Clients towards Financial Inclusion. A Draft Paper, Washington DC.

Gustman, A., \& Tom, S. (1999b). What People don't know about their Pensions and Social Security: An Analysis using Linked Data from the Health and Retirement Study. NBER Working Paper 7368.

Khandker, S. R. (1998). Fighting Poverty with Microcredit experience in Bangladesh. Oxford University Press, pp. xii 228.

Khandker, S. R. (2005). Microfinance and Poverty: Evidence Using Panel Data from Bangladesh. The World Bank Economic Review, 19(2), 263-286. 
Klapper, L. F., Lusardi, A., \& Panos, G. A. (2012). Financial Literacy and the Financial Crisis, National Bureau of Economic Research, (NBER) Working Paper Series, Working Paper 17930.

Lusardi A., \& Mitchelli, O. S. (2011). Financial Literacy around the World: An Overview. J. Pen. Econs. Finance, 10(4), 497-508.

Lusardi, A. (2002). Explaining why so many Households do not save. Dartmouth College Working Paper.

Lusardi, A., \& Mitchelli, O. (2007). Financial literacy and retirement preparedness: Evidence and implications for financial education. Business Economics, 42(1), 35-44.

OECD. (2006). The Importance of Financial Educatio. Policy Brief July 2016. http://www.oecd.org/publications/policy briefs

Russia G20 Presidency and the OECD. (2013). Advancing National Strategies for Financial Education. 320pp.

Simon, S., \& Ales, T. (2013). The Meaning and Concept of Financial Education in the Society of Economic Changes.

The Master Card Foundation, Microfinance Opportunities and Genesis Analytics (2011). Taking stock: Financial Education Initiatives for the Poor Synthesis Report. Global Study on Financial Education: Report.

Van Rooij, M. C., Lusardi, A., \& Alessie, R. J. (2012). Financial literacy, retirement planning and household wealth. The Economic Journal, 122(560), 449-478.

Van Rooij, M., Lusardi, A., \& Alessie, R. (2011). Financial literacy and stock market participation. Journal of Financial Economics, 101(2), 449-472.

Xu, L., \& Zia, B. (2012). Financial Literacy around the World: An overview of the Evidence with practical suggestions for the way forward. Policy Research Working paper 6107, The World Bank Development Research Group, Finance and Private Sector Development Team, June.

\section{Copyright Disclaimer}

Copyright for this article is retained by the author(s), with first publication rights granted to the journal.

This is an open-access article distributed under the terms and conditions of the Creative Commons Attribution license (http://creativecommons.org/licenses/by/3.0/). 